\title{
Inflammation Markers in Adipose Tissue and Cardiovascular Risk Reduction by Pomegranate Juice in Obesity Induced by a Hypercaloric Diet in Wistar Rats
}

\author{
Maria Monica Michicotl-Meneses ${ }^{1}$ (D), María del Rocío Thompson-Bonilla ${ }^{2}$, César A. Reyes-López ${ }^{3}$ (D), \\ Blanca Estela García-Pérez ${ }^{4}$ (D), Itzel I. López-Tenorio ${ }^{1}$, Cynthia Ordaz-Pichardo ${ }^{5}$ D \\ and María Eugenia Jaramillo-Flores ${ }^{1, *}$
}

Citation: Michicotl-Meneses, M.M.; Thompson-Bonilla, M.d.R.;

Reyes-López, C.A.; García-Pérez, B.E.; López-Tenorio, I.I.; Ordaz-Pichardo, C.; Jaramillo-Flores, M.E. Inflammation Markers in Adipose Tissue and Cardiovascular Risk Reduction by Pomegranate Juice in Obesity Induced by a Hypercaloric Diet in Wistar Rats. Nutrients 2021, 13, 2577. https://doi.org/10.3390/ nu13082577

Academic Editors: Cristiana Caliceti and Silvia Cetrullo

Received: 7 July 2021

Accepted: 25 July 2021

Published: 27 July 2021

Publisher's Note: MDPI stays neutral with regard to jurisdictional claims in published maps and institutional affiliations.

Copyright: (c) 2021 by the authors. Licensee MDPI, Basel, Switzerland. This article is an open access article distributed under the terms and conditions of the Creative Commons Attribution (CC BY) license (https:// creativecommons.org/licenses/by/ $4.0 /)$.
1 Departamento de Ingeniería Bioquímica, Instituto Politécnico Nacional, Escuela Nacional de Ciencias Biológicas, Mexico City 07738, Mexico; michicotlm4@gmail.com (M.M.M.-M.); itzeltenorio20@hotmail.com (I.I.L.-T.)

2 Laboratorio de Medicina Genómica, Investigación Biomédica y Traslacional, ISSSTE, Hospital Regional “1 de Octubre”, Mexico City 07760, Mexico; rociothompson@yahoo.com.mx

3 Laboratorio de Bioquímica Estructural, Instituto Politécnico Nacional,

Escuela Nacional de Medicina y Homeopatía, Mexico City 07320, Mexico; careyes@ipn.mx

4 Laboratorio de Microbiología General, Instituto Politécnico Nacional, Escuela Nacional de Ciencias Biológicas, Mexico City 11340, Mexico; abrilestela@hotmail.com

5 Laboratorio de Biología Celular y Productos Naturales, Instituto Politécnico Nacional, Escuela Nacional de Medicina y Homeopatía, Mexico City 07320, Mexico; dra_cynthia@hotmail.com

* Correspondence: mjarfl@ipn.mx; Tel.: +52-55-57-29-6000

Abstract: Pomegranate juice (Punica granatum) has been used since ancient times in traditional medicine (Unani Medicine, Ayurveda); its main compounds are anthocyanins and ellagic acid, which have anti-inflammatory, antioxidant, hepatoprotective, and cardiovascular health effects. The objective was to evaluate the effect of pomegranate juice on inflammation, blood pressure, and vascular and physiological markers associated with obesity induced by a high-fat diet in a murine model. The results show that pomegranate juice reduces the concentration of low-density lipoprotein cholesterol (cLDL) 39\% and increases the concentration of high-density lipoprotein cholesterol (cHDL) by $27 \%$, leading to a $12 \%-18 \%$ decrease in the risk of cardiovascular diseases (CVD). In addition to reducing blood pressure by $24 \%$, it also had an antiatherogenic effect by decreasing sE-selectin levels by $42 \%$. On the other hand, the juice significantly increased adiponectin levels in adipose tissue, decreased levels of inflammation markers (tumor necrosis factor- $\alpha$ (TNF- $\alpha$ ), plasminogen activator inhibitor-1 (PAI-1), interleukin-17A (IL-17A), interleukin-6 (IL-6), interleukin$1 \beta$ (IL-1 $\beta)$ ), and inhibited the monocyte chemoattractant protein-1 (MCP-1). Pomegranate juice requires clinical studies to prove its immunoregulatory and therapeutic effects on cardiovascular and atherogenic risks.

Keywords: pomegranate juice; anthocyanins; obesity; pro-inflammatory cytokines; inflammation; selectin; atherosclerosis vascular risk; high-fat diet

\section{Introduction}

Metabolic diseases, including obesity, are one of the main public health problems. Obesity is the excessive accumulation of visceral and subcutaneous fat from adipose tissue (AT), and this accumulation is strongly associated with alterations in lipid metabolism, endothelial dysfunction, insulin resistance, dysregulation of adipokines expression, and inflammation. These changes are considered a risk factor for developing metabolic syndrome (MS), type 2 diabetes (T2DM), cardiovascular disease (CVD), non-alcoholic fatty liver (NAFLD), endothelial damage, atherosclerosis, and hypertension [1,2]. All of these diseases contribute to the high mortality and morbidity rates prevalent worldwide. 
In recent years, strong evidence has highlighted the main role of inflammation as the mechanism responsible for making obesity a risk factor in developing these metabolic complications [3,4]. The inflammation of adipose tissue promotes the loss of the immune regulation and favors the infiltration and activation of immune cells, which in turn, produce increased levels of pro-inflammatory cytokines, such as interleukin 6 (IL-6), interleukin $1 \alpha(\mathrm{IL}-1 \alpha)$, interleukin $1 \beta$ (IL-1 $\beta)$, tumor necrosis factor (TNF- $\alpha)$, plasminogen activator inhibitor-1 (PAI-1), and monocyte chemoattractant protein-1 (MCP-1). Moreover, the persistence of M1-polarized macrophages contributes to maintenance of the low-grade chronic inflammation in obesity [5]. Moreover, the dysfunction of adipose tissue leads to a dysregulated production in the levels of anti-inflammatory adipokines (adiponectin) [6]. Obesity is also associated with endothelial dysfunction and stimulation of the proliferative response in the vascular wall, thus promoting an increased risk of cardiovascular diseases (CVD), such as dyslipidemia, thrombosis, atherogenesis, atherosclerosis, and hypertension [7]. Endothelial dysfunction is generated by exposure to an activating stimulus, for instance, proinflammatory cytokine secretion, triglyceride elevation, decreased highdensity lipoprotein cholesterol (HDL-C), and increased low-density lipoprotein cholesterol (LDL-C) $[7,8]$, which induce the expression of cell adhesion molecules on the endothelial surface, such as vascular cell adhesion molecule 1 (VCAM -1), the intercellular adhesion molecule 1 (ICAM-1), and E-selectin, that participate in the inflammatory reaction, as well as high levels of nitric oxide (NO) produced by inducible nitric oxide synthase (iNOS), ultimately promoting atherosclerosis [9]. The role of anti-inflammatory cytokines, such as adiponectin secreted by adipose tissue (whose levels in obese patients are decreased compared to healthy people), is to improve insulin sensitivity by increasing energy expenditure and the oxidation of fatty acids through the phosphorylation of protein kinase (AMPK) activated by 5-adenosine monophosphate (5-AMP) through increased expression of Peroxisomal Proliferators-Activated Receptors (PPAR's), Cluster of Differentiation 36 (CD36), acyl-coenzyme oxidase, and uncoupling protein 2 (UCP2) genes [10]. On the other hand, its vasculoprotective function has been demonstrated since it attenuates monocyte adhesion to endothelial cells, mainly by the inhibition of TNF- $\alpha$ and the synthesis of intercellular adhesion molecule 1 (ICAM-1), the molecule of cell adhesion 1 (VCAM 1), and E-selectin; therefore, adiponectin limits the onset of atherosclerotic plaque [11].

Since the collected evidence indicates that a state of chronic inflammation has a crucial role in the pathogenesis of obesity-related metabolic dysfunction, where clinical and epidemiological studies describe a clear connection between high levels of proinflammatory cytokines with atherosclerotic lesions that favor cardiovascular events [12], several efforts to integrate interventions targeting lowering the inflammation burden have been carried out [13].

Pomegranate (Punica granatum) is an edible fruit whose nutraceutical and pharmacological properties have been reported [14,15]. Its main antioxidant compounds are hydrolysable tannins, anthocyanins (3-glycosides and 3,5-glycosides of delphinidin, cyanidin, and pelargonidin) and derivatives of ellagic acid. There are some differences in the composition of phenolic compounds between processed and natural juices, due to, among others, the type of process, cultivation, and growing conditions [16,17]. Studies in cell cultures, mice, and humans show the effect of flavonoids present in the juice, which are associated with the prevention of cardiovascular diseases, obesity, diabetes, and cancer [18].

The consumption of natural or concentrated pomegranate juice has beneficial effects on human health, since prolonged supplementation, in vitro and in vivo, with pomegranate juice concentrate and pomegranate fruit extract ameliorated the perturbed shear stressinduced atherogenesis by increasing the activity of endothelial nitric oxide synthase (eNOS) and reducing the protein levels of oxidation-sensitive responsive genes (ELK-1 and pCREB) [19]. Consuming $200 \mathrm{~mL} /$ day of pomegranate juice for 6 weeks in patients with T2DM decreased systolic pressure and diastolic pressure and improved the lipid profile, reducing total cholesterol and LDL-c without effect on HDL-c [20]. Additionally, daily supplementation with $20 \mathrm{~g}$ of microencapsulated pomegranate for 30 days reverses 
endothelial dysfunction and reduces postprandial triglyceridemia in women with acute coronary syndrome [21]. Therefore, the objective of this study was to evaluate the effect of pomegranate juice on the markers of inflammation (TNF- $\alpha$, IL-1 $\beta$, IL-6, MCP-1, and PAI- 1 ) in retroperitoneal adipose tissue, which is associated with markers of vascular disorders (E-selectin, cHDL y cLDL) and metabolic alterations in obesity.

\section{Materials and Methods}

\subsection{Study Material}

The fruit of ripe Punica granatum Tecozautla cultivar from the San Nicolas de los Ranchos and Huejotzingo, Puebla, Mexico, was used, which is characterized as a fruit of thin yellowish green skin, dark red, sweet aryl, and semi-hard seed.

\subsection{Obtaining the Pomegranate Juice}

Fresh pomegranate fruits were selected from the Punica granatum Tecozautla cultivar for their physical and sensory characteristics, indicating they were appropriate to be consumed, such as the external color light red and greenish yellow; internal color: red; flavor: sweet and sour, sweet predominates; appearance: globular with $10 \mathrm{~cm}$ wide without physical defects; and free of pests and diseases (CXS 310-2013). The fruits were washed to extract manually the peel, endocarp, and aryls; they were stored at $-80^{\circ} \mathrm{C}$ for later use. The aryls were pressed manually to obtain the juice, which was stored in an amber bottle at $-80^{\circ} \mathrm{C}$ for later use.

\subsection{Quantification of Total Anthocyanins}

The differential $\mathrm{pH}$ method was used [22]. The concentration of total monomeric anthocyanins was determined as follows: in a test tube, $1 \mathrm{~mL}$ of the sample and $7 \mathrm{~mL}$ of a potassium chloride buffer ( $\mathrm{pH}$ 1.0) were placed; in another tube, $1 \mathrm{~mL}$ of the sample and $7 \mathrm{~mL}$ of a sodium acetate buffer $(\mathrm{pH} 4.5)$ were placed, allowing them to react in the dark for $15 \mathrm{~min}$. Absorbance readings at $510 \mathrm{~nm}$ and $700 \mathrm{~nm}$ were taken in a UV-Visible Spectrophotometer (Genesys 10S UV-Vis, Thermo Scientific, Madison, WI, USA). The results were expressed as $\mathrm{mg}$ of cyanidin-3-glycoside equivalent per kilogram sample $\left(\mathrm{C}_{3} \mathrm{~g} \mathrm{Eq} / \mathrm{Kg}\right.$ of juice).

The calculations were carried out using the following equations:

$$
\begin{gathered}
\qquad \mathrm{A}=\left(\mathrm{Abs}_{510}-\mathrm{Abs}_{700}\right) \mathrm{pH} 1 \cdot 0-\left(\mathrm{Abs}_{510}-\mathrm{Abs}_{700}\right) \mathrm{pH} 4 \cdot 5 \\
\text { Concentration Monomeric Anthocyanins }(\mathrm{MAC})=\frac{(\mathrm{A} \times \mathrm{MW} \times \mathrm{FD})}{\varepsilon \times \mathrm{L}} \times 100
\end{gathered}
$$

where: $\mathrm{A}=$ absorbance; $\varepsilon=$ molar absorptivity cyanidin-3-glucoside (26.900); $\mathrm{MW}=$ molecular weight cyanidin-3-glucoside ( $449.2 \mathrm{~g} / \mathrm{mol})$; FD = dilution factor; $\mathrm{L}=$ cell length.

\subsection{Determination of Total Phenols}

The phenolic compounds of the juice were determined by the method described by Herald et al. [23]; a SINERGY H1 microplate reader was used (Biotek, Winoosky, VT, USA). In a 96-well plate, $75 \mu \mathrm{L}$ of distilled water was added followed by $25 \mu \mathrm{L}$ of the sample or standard and $25 \mu \mathrm{L}$ of Folin-Ciocalteu reagent (1:1); they were allowed to react for 6 min, and then $100 \mu \mathrm{L}$ of $\mathrm{Na}_{2} \mathrm{CO}_{3}$ was added $(75 \mathrm{~g} / \mathrm{L})$. The plate was covered and kept in the dark for $90 \mathrm{~min}$. The absorbance was measured at $750 \mathrm{~nm}$ in triplicate using gallic acid as a standard at concentrations between 12.5 and $200 \mu \mathrm{g} / \mathrm{mL}$. The results obtained are expressed as mg of gallic acid (AG) Eq/g of sample.

Phenol Compounds Identification

The identification of phenolic compounds in pomegranate juice was carried out by reversed phase HPLC on an Agilent 1260 Infinity ${ }^{\circledR}$ HPLC (Agilent Technologies, Santa Clara, CA, USA) with a quaternary pump, automatic injector and detector of diode array (HPLC-DAD), HPLC DAD software, and Zorbax C-18 column with an internal diameter 
of $150 \times 4.6 \mathrm{~mm} 0.5 \mu \mathrm{m}$ (Agilent Technologies Inc. Santa Clara, CA, USA) with injection volume $10 \mu \mathrm{L}$ and flow $0.5 \mathrm{~mL} / \mathrm{min}$, as reported in [24].

\subsection{Animal Testing}

For the study, 6-week-old male Wistar rats ( $180 \pm 10 \mathrm{~g}$ body weight) acquired from UPEAL CINVESTAV-IPN (Zacatenco, CDMX, Mexico City, Mexico) were used. All animals received food and water ad libitum and were housed in stainless steel cages with sterile beds under controlled conditions of temperature $\left(22 \pm 2{ }^{\circ} \mathrm{C}\right)$ and relative humidity (50 $\pm 10 \%$ ) with light-dark cycles of $12 \mathrm{~h}$ (9:00-21:00) [21]. The treatment and euthanasia were carried out in accordance with the approval of the BioEthics Committee of the Escuela Nacional de Medicina y Homeopatía CBE/005/2021, complying with the guide for the care, use, and humanitarian sacrifice of the laboratory Animals of the Mexican Animal Care Council (Consejo Mexicano del Cuidado Animal) (NOM-033-ZOO-1995, NOM-062-ZOO-1999) and guidelines of the International Committee. The animals were randomly distributed in 3 groups, standard diet (SD), high-fat diet (HD), and high-fat diet plus pomegranate juice (JP), with an $n=6$ for each group.

The animals were subjected to an acclimatization period of 1 week prior to the start of the study, which lasted 8 weeks. The SD group was fed with a standard diet (Rodent Laboratory Chow 5001; PMI Nutrition International, St. Louis, MO, USA) and the high-fat diet (HD) and pomegranate juice (JP) groups were fed a high-fat (HD) diet (TD. 88137; Teklad Global Harlan Laboratories, Inc.). The nutritional composition of the standard diet was: $23 \%$ of total protein; $46.5 \%$ of carbohydrates and $4.5 \%$ of fat, corresponding to an energy value of $3.1 \mathrm{kcal} / \mathrm{g}$; and the composition of the high fat diet was: $15.2 \%$ protein, $42.8 \%$ carbohydrates, and $42 \%$ fat, containing $195 \mathrm{~g} / \mathrm{kg}$ of casein, $3 \mathrm{~g} / \mathrm{kg}$ of DL-methionine, $340 \mathrm{~g} / \mathrm{kg}$ of sucrose, $140.5 \mathrm{~g} / \mathrm{kg}$ of cornstarch, $210 \mathrm{~g} / \mathrm{kg}$ of butter, $50 \mathrm{~g} / \mathrm{kg}$ of cellulose, $43 \mathrm{~g} / \mathrm{kg}$ of mineral MIX, $15 \mathrm{~g} / \mathrm{kg}$ of vitamin MIX, $2 \mathrm{~g} / \mathrm{kg}$ of choline, $1.5 \mathrm{~g} / \mathrm{kg}$ of cholesterol, and an energy content of $4.5 \mathrm{Kcal} / \mathrm{kg}$. The SD and HD groups were given water as a placebo, and the JP group was given pomegranate juice as treatment $(10 \mathrm{~mL} / \mathrm{Kg}$ of body weight daily) intragastrically.

\subsection{Food and Energy Consumption and Body Weight}

The average weekly food consumption was calculated, and caloric intake was determined by calculating food consumption multiplied by dietary energy density.

The animals were weighed at the beginning of the treatment, monitoring the body weight of each rat 3 times per week during the study period.

\subsection{Adipose Tissue Extraction}

At the end of the study period ( 8 weeks), prior to the administration of ketamine and xylazine ( 35 and $5 \mathrm{mg} / \mathrm{kg}$ ) for the euthanasia of the animals, they were subjected to a $12 \mathrm{~h}$ fast. Retroperitoneal and epididymal adipose tissue were obtained, which were washed with a $1 \times$ phosphate saline (PBS), weighed and frozen immediately, and stored at $-80{ }^{\circ} \mathrm{C}$ for later use.

\subsection{Insulin Tolerance}

The insulin tolerance test was performed at week 8 of the treatment; the animals were subjected to a $4 \mathrm{~h}$ fast, taking blood samples by tail puncture to determine the level of blood at time zero to baseline measures. Subsequently, $0.06 \mathrm{IU} / \mathrm{Kg}$ body weight of recombinant human insulin (Humulin R, from Eli Lilly, Mexico City, Mexico) was administered to determine if they exhibited insulin resistance (IR); blood samples were taken after injection intraperitoneally at 30,60,90,120, and $150 \mathrm{~min}$. Glucose levels were determined by using a glucometer (ACCU-CHEK ${ }^{\circledR}$ Performa, Roche Diagnostic, Indianopolis, IN, USA) [25]. 


\subsection{Determining Systolic and Diastolic Blood Pressure}

The pressure was measured at the end of week 7 of the treatment by the method of tail-cuff plethysmography (non-invasive method) with a pressure gauge Brand IITC Life Science model MRBP System. The animals were placed in a containment device (sepo) for measurement purposes with a noise-free environment prior to the 1-week training until the reading [26].

\subsection{Lipid Profile}

Serum triglyceride and total cholesterol levels were determined by using the RANDOX Kit: total cholesterol RX MONZA CH 200, Triglycerides RX MONZA TR 210, HDL RX SUZUKA CH 8033 (Randox Laboratories Limited, Crumlin, UK) in a SELECTRA II VITA Lab device from Wiener Lab. Blood samples were taken from the abdominal aorta in BD Vacutainer ${ }^{\mathrm{TM}}$ SST tubes, which were centrifuged at $2325 \times \mathrm{g}$ for $15 \mathrm{~min}$ at $4{ }^{\circ} \mathrm{C}$ to obtain the serum. The determinations were made in triplicate. The methodology was performed according to the kit protocol.

\subsection{Determining Vascular Markers}

The levels of sE-selectin, Intercellular adhesion molecule (sICAM), von Willebrand Factor (VWF), and adiponectin were determined in the serum by using the MILLIPLEX ${ }^{\circledR}$ MAP Rat Vascular Injury Magnetic Bead Panel 2 Toxicity Multiplex RVMAG-26K-04 Commercial Kit, which was purchased with MILLIPORE (Billerica, MA, USA). The serum was obtained by taking abdominal aortic blood in BD Vacutainer ${ }^{\mathrm{TM}}$ SST tubes, which were centrifuged at $2325 \times \mathrm{g}$ for $15 \mathrm{~min}$ at $4{ }^{\circ} \mathrm{C}$. The determinations were made in triplicate. The MAGPIX ${ }^{\circledR}$ Luminex device was used. The methodology was performed according to the kit's protocol.

\subsection{Determining Inflammation Markers}

Retroperitoneal adipose tissue (100 mg) was homogenized in $700 \mu \mathrm{L}$ of an extraction buffer for the RIPA lysis assay $\left(50 \mathrm{mM} \mathrm{NaH}_{2} \mathrm{PO}_{4}, 100 \mathrm{mM} \mathrm{Na}_{2} \mathrm{HPO}_{4}, 0.1 \%\right.$ sodium dodecyl sulfate, $0.5 \% \mathrm{NaCl}, 1 \%$ Triton X-100, $1 \mathrm{mM}$ EDTA), and they were frozen with liquid nitrogen until use. Then, they were thawed and centrifuged at $2325 \times \mathrm{g}$ at $4{ }^{\circ} \mathrm{C}$ to obtain the supernatant and determine Leptin, $\mathrm{TNF} \alpha, \mathrm{PAI}-1$, Insulin, IL1- $\alpha$, IL- $1 \beta$, IL- 6 , and IL-10 levels. The concentrations of Leptin, TNF $\alpha$, PAI-1, and Insulin were determined by immunoassay with commercial kit MILLIPLEX ${ }^{\circledR}$ MAP Rat Adipokine Panel-Metabolism Assay RADPKMAG-80K (MILLIPORE), and IL1- $\alpha$, IL-1 $\beta$, IL-6, and IL-10 levels were determined by commercial kit MILLIPLEX MAP Rat Cytokine/Chemokine Magnetic Bead Panel-Immunology Multiplex Assay (MILLIPORE). The MAGPIX ${ }^{\circledR}$ Luminex equipment was used; all determinations were performed in triplicate, and the results were expressed in $\mathrm{pg} / \mathrm{g}$ adipose tissue (AT).

\subsection{Statistical Analysis}

The results were previously subjected to normality tests in order to define the statistical test for analysis. The results are expressed as mean values \pm standard error. Statistical analysis was determined by a one-way ANOVA, and comparisons between the groups were evaluated by using the Bonferroni or Tukey test for multiple comparisons with a significance level of $\alpha \leq 0.05$. The results are expressed as mean values \pm standard error. Statistical analysis was determined by non-parametric tests; comparisons between groups were evaluated by using the Mann-Whitney-Wilcoxon test with a level of significance of $\alpha<0.05$.

\section{Results and Discussion}

\subsection{Chemical Composition, Phenolic Compounds}

The content of total phenolic compounds and anthocyanins present in the juice were $6.17 \mathrm{mg} \mathrm{AG} \mathrm{Eq} / \mathrm{mL}$ and $0.191 \mathrm{mg} \mathrm{C} 3 \mathrm{~g} \mathrm{Eq} / \mathrm{mL}$, respectively, compared to the content of phe- 
nolic compounds of the juice of 10 pomegranate cultivars in four regions of China, where the concentration of polyphenols and anthocyanins ranged between 3.15 and $7.43 \mathrm{mg} \mathrm{GaE} / \mathrm{mL}$ and between 0.004 and $0.160 \mathrm{mg} \mathrm{CyE} / \mathrm{mL}$, respectively [24]. The maximum concentrations found in both groups of compounds are very similar to those of this work, only with a difference of $1.2 \mathrm{mg} \mathrm{GaE} / \mathrm{mL}$ in phenols and $31 \mathrm{mg}$ of anthocyanins. In contrast, different extraction procedures were compared, in which they found no significant differences between them, showing contents for total phenols of 1.38 to $2.89 \mathrm{mg} \mathrm{GaE} / \mathrm{mL}$, and of anthocyanins between 0.109 and $0.139 \mathrm{mg} \mathrm{C3gE/mL} \mathrm{[27],} \mathrm{much} \mathrm{lower} \mathrm{values} \mathrm{than} \mathrm{those}$ reported here. The results of the phenol content of this study are two times more than those reported by Mphahlele et al. (2016), whereas in the anthocyanin content, there is no difference.

Regarding the content of phenolic compounds and anthocyanins in pomegranate juice, it has been reported that it contains from 6 to 65 different anthocyanins, some evaluated by HPLC and others by HPLC-MS, which explains the great difference, while in relation to phenolic compounds, up to 86 are reported, which include those from phenolic acids, flavonoids, and ellagitannins and others not identified. Within this large number of bioactive compounds of a phenolic nature, 35 of them are the main ones, highlighting pelargonidine-3,5-diglucoside, cyanidine-3-glucoside, catechin gallato, catechin, and, in lower concentrations, punicalagin $\alpha$ and $\beta$ [28-32]. In the present work, punicalagin, catechin, chlorogenic acid, gallic acid, ferulic acid, caffeic acid, and ellagic acid were identified by HPLC-DAD.

\subsection{Effect of Pomegranate Juice on Physiological Parameters}

The results of the physiological and biochemical markers obtained in the animal model are shown in Table 1. It is observed that the total body weight gain was greater for the HD control group, with $312.5 \mathrm{~g}$, while the group treated with pomegranate juice (JP) had $25 \%$ less weight, since it only reached $234.6 \mathrm{~g}$, even though both groups consumed a high-fat diet. With a balanced diet, it is possible to maintain a normal weight, which hardly happens with a high calorie intake. Therefore, the effect of the JP treatment is relevant, since it reduces weight and adiposity; this can be seen in the retroperitoneal adipose tissue that was reduced by $15 \%$. Since ellagic acid inhibits adipogenesis by modifying chromatin in preadipocytes, thereby reducing adiposity [33], the reduction in adipose tissue is likely due in part to the ellagic acid.

The weight gain is a consequence of the amount of food consumption and the corresponding energy intake. The HD group increased their weight by consuming $25 \mathrm{~g} /$ day of food with an energy ingested of $113.5 \mathrm{Kcal} /$ day of a hypercaloric diet, unlike the JP group that had a decrease in food consumption of $7 \%$ and energy ingested of $107 \mathrm{Kcal} /$ day. These results suggest that the effect of pomegranate juice on weight reduction in animals with a hypercaloric diet may be due to a decreased appetite. The appetite suppressant effect of pomegranate juice may be due to an inhibitory effect on the production of ghrelin, a gastric hormone that regulates appetite [34], or its potential ability to regulate leptin levels, so that it prevents hyperleptinemia [33,34]. After food intake, leptin levels doubled in obese rats compared to healthy rats, with $4 \mathrm{ng} / \mathrm{mL}$ and $2 \mathrm{ng} / \mathrm{mL}$, respectively, while after $24 \mathrm{~h}$ of fasting, the reported values were $2 \mathrm{ng} / \mathrm{mL}$ for obese rats and $1 \mathrm{ng} / \mathrm{mL}$ for healthy rats [35].

The excessive intake of a high-fat diet triggers the deregulation of body weight generating obesity, associated with endocrine and metabolic changes. This behavior was reflected in the HD control group with $3.8 \%$ retroperitoneal adipose tissue and $2.6 \%$ epididymal adipose tissue, which significantly increases the risk of cardiovascular complications, NAFLD, insulin resistance, atherosclerosis, dyslipidemia, and T2DM. The JP treatment suggests an anti-obesity effect, since it reduces the retroperitoneal adipose tissue by $15 \%$ with respect to the HD, although without effect on the epididymal adipose tissue.

Intra-abdominal adipose tissue (retroperitoneal and peritoneal) [36] contributes to the appearance of metabolic disorders, such as glucose dysregulation, generating hyper- 
glycemia that is associated with insulin resistance [37,38]. In humans, ellagic acid has been reported to reduce blood glucose levels [39].

Table 1. Physiology parameters evaluated in the murine study model.

\begin{tabular}{cccccccc}
\hline Parameters & \multicolumn{2}{c}{ Group SD } & \multicolumn{2}{c}{ Group HD } & \multicolumn{2}{c}{ Group JP } \\
\hline Food consumption (g/day) & $28.21^{\mathrm{a}}$ & \pm 0.34 & $25.37^{\mathrm{b}}$ & \pm 0.80 & $23.72^{\mathrm{c}}$ & \pm 0.16 \\
Energy consumption (Kcal/day) & $87.45^{\mathrm{a}}$ & \pm 1.07 & $113.5^{\mathrm{b}}$ & \pm 3.87 & $106.78^{\mathrm{c}}$ & \pm 0.70 \\
Gain in body weight (g) & $212.6^{\mathrm{a}}$ & \pm 4.26 & $312.5^{\mathrm{b}}$ & \pm 8.13 & $234.62^{\mathrm{a}}$ & \pm 7.30 \\
Retroperitoneal adipose tissue (\%) & $1.9^{\mathrm{a}}$ & \pm 0.03 & $3.8^{\mathrm{b}}$ & \pm 0.12 & $3.24^{\mathrm{c}}$ & \pm 0.09 \\
Epididymal adipose tissue (\%) & $1.48^{\mathrm{a}}$ & \pm 0.04 & $2.59^{\mathrm{b}}$ & \pm 0.18 & $2.67^{\mathrm{b}}$ & \pm 0.08 \\
Glucose (mg/dL) & $112.3^{\mathrm{a}}$ & \pm 0.97 & $128.2^{\mathrm{b}}$ & \pm 3.49 & $115.5^{\mathrm{a}}$ & \pm 2.95 \\
Systolic pressure (mmHg) & $117.7^{\mathrm{a}}$ & \pm 1.26 & $141.9^{\mathrm{b}}$ & \pm 1.68 & $112.61^{\mathrm{a}}$ & \pm 0.16 \\
Diastolic pressure (mmHg) & $90.33^{\mathrm{a}}$ & \pm 2.67 & $116.7^{\mathrm{b}}$ & \pm 2.46 & $88.89^{\mathrm{a}}$ & \pm 2.69 \\
\hline
\end{tabular}

SD: standard diet; HD: high-fat diet; JP: high-fat diet + pomegranate juice. Values represent the mean \pm standard error. Statistical analysis was determined by using a one-way ANOVA followed by the Bonferroni test for multiple comparisons with a level of significance of $p \leq 0.05$. Different letters $\left({ }^{a},{ }^{b}\right.$ and $\left.{ }^{c}\right)$ indicate statistical significance between the groups (columns).

Regarding blood pressure, the results obtained showed that the treatment decreased systolic pressure from 142 to $112.61 \mathrm{mmHg}$ and reduced the diastolic pressure from 116.7 to $88.89 \mathrm{mmHg}$, with the blood pressure values reaching those of the SD group. These results indicate that pomegranate juice can regulate blood pressure to normal levels (100-120 mmHg in systolic pressure and $84-90 \mathrm{mmHg}$ in diastolic pressure) [40-42]. Ellagic acid, one of the main components of pomegranate juice, reduces blood pressure in hypertensive rats, probably improving the bioavailability of nitric oxide [43], as well as catechin and ferulic acid, the latter attenuating oxidative stress [44,45]. Epidemiological studies have shown that blood pressure and obesity are risks for cardiovascular disease [39]. A clear association of weight gain with hypertension has been demonstrated, since $60 \%$ of hypertension is attributed to the increase in adipose tissue stores, where obese people are 3.5 times more likely to have hypertension compared to healthy individuals. Data from the National Health and Nutrition Examination Survey (NHANES) indicate that the prevalence of hypertension among obese people with a body mass index (BMI) $>30 \mathrm{~kg} / \mathrm{m}^{2}$ is $42.5 \%$ compared to $15.3 \%$ for thin people [46]. They studied in Wistar rats with diabetes and hypertension induced with Streptozotocin and Angiotensin II (STZ and Ang II) the effect of dehydrated and concentrated pomegranate juice under reduced pressure (pomegranate juice extract) in doses of 100 and $300 \mathrm{mg} / \mathrm{Kg} /$ day for 4 weeks. They observed a $36 \%$ reduction in blood pressure with respect to diabetic and hypertensive groups, but without difference with the control group (healthy), indicating beneficial effects of the pomegranate juice extract on blood pressure in both diabetes and hypertension [47]. A decrease in blood pressure was obtained in this study, and therefore the risk of suffering from cardiovascular diseases in obese patients, agreeing with the previously mentioned studies [48]; this is probably due to the anthocyanins and ellagic acid present in pomegranate juice $[43,44]$.

\subsection{Lipid Profile}

The levels of total cholesterol, triglycerides, c-HDL, and c-LDL (Table 2) showed that the levels of total cholesterol were not modified, while the ratio of cHDL-cLDL was favorably modified, such that cHDL $5.87 \mathrm{mg} / \mathrm{dL}$ was increased and LDL-C decreased by $6.3 \mathrm{mg} / \mathrm{dL}$ with treatment. Furthermore, there was a slight increase $(7 \%)$ in triacylglycerides; this is probably due to the sugar content of the juice. Elevated levels of c-HDL have been associated with the reduction in cardiovascular disease risks [45].

Experimental evidence in humans and animal models confirms that increased levels of c-HDL reduces atherosclerosis, since every $1 \mathrm{mg} / \mathrm{dL}(0.0259 \mathrm{mmol} / \mathrm{L})$ of increased c-HDL equals a $2 \%-3 \%$ reduced risk of cardiovascular diseases (CVD) [49], which would be equivalent to a risk reduction of between $12 \%-18 \%$ with this treatment. The anthocyanins present in the juice suggest a protective effect to risks of atherosclerosis and cardiovascular 
diseases. Likewise, preclinical and clinical studies have evaluated the bioactivity of dietary anthocyanin intake, and it is associated with beneficial changes in serum biomarkers in human populations (hyperlipidemic, hypertensive, or diabetic) that include not only the levels of cHDL, but also its anti-inflammatory, antioxidant, vasodilator, and/or antithrombotic properties. Therefore, it has been proposed that anthocyanins inhibit the activation of the nuclear factor $\mathrm{kB}(\mathrm{NF}-\mathrm{kB})[50]$.

Table 2. Lipidic profile and vascular parameters in serum.

\begin{tabular}{|c|c|c|c|c|c|c|c|c|c|c|}
\hline \multirow{5}{*}{ 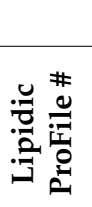 } & \multirow{4}{*}{$\begin{array}{c}\text { Parameters } \\
\text { Cholesterol }(\mathrm{mg} / \mathrm{dL}) \\
\text { cHDL }(\mathrm{mg} / \mathrm{dL}) \\
\text { cLDL }(\mathrm{mg} / \mathrm{dL})\end{array}$} & \multicolumn{3}{|c|}{ Group SD } & \multicolumn{3}{|c|}{ Group HD } & \multicolumn{3}{|c|}{ Group JP } \\
\hline & & $38.66^{a}$ & \pm & 0.70 & $54.76^{\mathrm{b}}$ & \pm & 2.51 & $54.76^{\mathrm{b}, \mathrm{c}}$ & \pm & 2.08 \\
\hline & & $20.68^{a}$ & \pm & 0.71 & $22.48^{\mathrm{a}}$ & \pm & 1.75 & $28.35^{b}$ & \pm & 1.12 \\
\hline & & $10.13^{a}$ & \pm & 0.90 & $15.60^{b}$ & \pm & 1.91 & $9.54^{a, c}$ & \pm & 0.95 \\
\hline & Triglycerides (mg/dL) & $60.44^{\mathrm{a}}$ & \pm & 2.69 & $132.09^{b}$ & \pm & 3.40 & $142.30^{c}$ & \pm & 10.98 \\
\hline \multirow{4}{*}{ 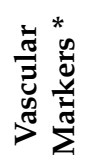 } & E- selectin $(\mathrm{ng} / \mathrm{mL})$ & $8.63^{a}$ & \pm & 0.15 & $11.03^{b}$ & \pm & 0.44 & $6.27^{c}$ & \pm & 0.04 \\
\hline & s-ICAM-1 (ng/mL) & $7.71^{\mathrm{a}}$ & \pm & 0.21 & $7.83^{a}$ & \pm & 0.24 & $7.36^{\mathrm{a}}$ & \pm & 0.11 \\
\hline & VWF (ng/mL) & $8.64^{\mathrm{a}}$ & \pm & 0.24 & $9.06^{\mathrm{a}}$ & \pm & 0.34 & $10.9^{b}$ & \pm & 0.49 \\
\hline & Adiponectin (ng/mL) & $70.39^{a}$ & \pm & 2.36 & $58.97^{\mathrm{b}}$ & \pm & 1.48 & $69.37^{\mathrm{a}}$ & \pm & 1.17 \\
\hline
\end{tabular}

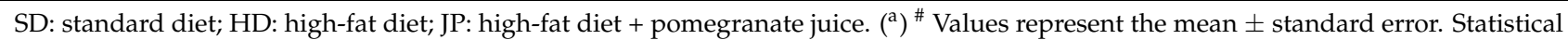
analysis for biochemical parameters was determined by using a one-way ANOVA followed by the Tukey test for multiple comparisons with a significance level of $p \leq 0.05$. Different letters indicate statistical significance between the groups (columns). ( $\left({ }^{b}\right) *$ Values represent the mean \pm standard error. Statistical analysis for vascular parameters was determined by using a one-way ANOVA followed by the Bonferroni test for multiple comparisons with a significance level of $p \leq 0.05$. Different letters $\left({ }^{\mathrm{a}},{ }^{\mathrm{b}}\right.$ and $\left.{ }^{\mathrm{c}}\right)$ indicate statistical significance between the groups (columns).

The maximum reduction in LDL-C with statins ranged from $30 \%$ to $50 \%$, while the combination of statins with other drugs reduced it from $60 \%$ to $84 \%$ [51]. On the other hand, the comparison in the efficacy of different doses of atorvastatin versus simvastatin, pravastatin, lovastatin, and fluvastatin in hypercholesterolemic patients showed that atorvastatin 10, 20, and $40 \mathrm{mg}$ for 8 weeks reduced LDL-C by $38 \%, 46 \%$, and $51 \%$, respectively [52]. Various epidemiological studies have revealed that statins increase HDL-C by approximately $5 \%$ to $7 \%$ and that LDL-C decreases by an additional $5 \%-6 \%$ when the statin dose is doubled, compared to that achieved with the minimum dose of $10 \mathrm{mg}$ in such a way that these increasing statin doses do not progressively increase HDL-C levels, as is the case with atorvastatin [53]. Due to the above, pomegranate juice, given the results found in this study with an increase in HDL-C levels in 27\% and a reduction in LDL-C in 39\%, it is likely that the effect is due to the antioxidant power and the interaction of the different components of the juice, among others, the concentration of anthocyanins, since they have been shown to reduce blood pressure and arterial stiffness [54], such that clinical studies must be carried out that provide information on the effect on cholesterol levels, compared with the total or partial replacement of atorvastatin with the advantage of not generating side effects, such as the case of statins whose main side effects are muscle damage, generation of DT2, and bleeding risk (American Heart Association). Some further comparative studies in the same models are necessary to corroborate this assessment [55].

\subsection{Vascular Parameters}

Atherosclerosis is a disease characterized by a chronical arterial wall inflammation and endothelial dysfunction, among others. In this condition, the activated endothelial cells overexpress several cell adhesion molecules, such as vascular cell adhesion molecule-1 (VCAM-1), intercellular adhesion molecule-1 (ICAM-1), platelet endothelial cell adhesion molecule (PECAM-1), and selectins (E-selectin and P-selectin) on their surfaces. Since the estimation of these molecules could represent a vascular damage marker, in this model $\mathrm{E}$ selectin, ICAM1, and the von Willebrand factor (VWF) were evaluated.

The results show (Table 2) that the HD group presented higher levels of selectin $(11 \mathrm{ng} / \mathrm{mL})$ than the treatment group $(8.63 \mathrm{ng} / \mathrm{mL})$, which suggests a tendency to endothelial damage induced by a high-fat diet, while the group treated with pomegranate juice had decreased sE-S levels by $42 \%$, suggesting a regulator effect on endothelial damage; there- 
fore, the pomegranate juice has an antiatherogenic effect. The reduction in the sE-S levels in the group treated with the juice will surely prevent damage to the vascular endothelium since the initial rolling process would not be carried out.

In relation to ICAM-1, pomegranate juice has a tendency to reduce its levels. In view of the fact that the levels of sE-S were low in the treated group, even lower levels of ICAM-1 would be expected; thus, by extending the study time, a decrease with the treatment will likely be observed.

ICAM-1 is expressed in epithelial cells, fibroblasts, macrophages, and lymphocytes in small quantities, although it is hardly expressed in the endothelium, and it only increases in cases of acute and chronic inflammation generated by TNF- $\alpha$ and IL-1, increasing its circulating concentration. Previous studies have shown that supplementation with epigallocatechin in patients with clinically stable coronary heart disease improves endothelial function, so the effect may be due to both the gallic acid and catechin present in the juice $[54,56]$. As for the VWF factor, contrary to what was expected, it increased by $20 \%$ in the group treated with pomegranate juice compared to the control group. There was a marked imbalance between the VWF and A disintegrin-like and metalloprotease with thrombospondin type 1 motif no. 13 (ADAMTS13) induced by thrombosis that is caused by inflammation. Different mediators of inflammation (Il6, Il-8, TNF- $\alpha$, superoxide anions, histamine, and thrombin) produce an increase in VWF levels through various mechanisms [57]; therefore, it is probable that some of the cytokines that are elevated due to one of the different mechanisms involved increase in such a way that the compounds present in the juice cannot counteract this response. For an adequate explanation, additional studies focused on this factor are required.

The results suggest that some compounds present in the juice promote the increase in the VWF factor, in contrast to the net effect (low levels of HDL cholesterol, selectin, sICAM-1, and adiponectin) that shows an antithrombotic effect. In addition to previous evidence, pomegranate juice has a protective vascular effect; for example, in studies in mice with apolipoprotein E deficiency and supplemented with pomegranate juice, the size of the atherosclerotic lesions was reduced by $44 \%$ in addition to a decreased number of foam cells in such lesions.

Furthermore, it has been shown that the presence of pomegranate juice in the endothelial cells of the human coronary artery reverses the low regulation of nitric oxide synthase (eNOS) expression caused by the addition of oxLDL [58], probably due to the high content of antioxidant phenolic compounds, such as punicalagin, catechin, chlorogenic, gallic, ferulic, caffeic acid and ellagic acids, and anthocyanins.

Adiponectin levels (ADP) (Table 2) increased by 17\% with pomegranate juice, compared to the HD group. Low levels of adiponectin are associated with a state of inflammation in the adipose tissue generated by a high-calorie diet. In this model, the JP treatment stimulated adiponectin secretion; this adipokine has antidiabetic, anti-inflammatory, and antiatherogenic effects, in addition to causing an increased expression of molecules involved in the transport of fatty acids (CD36), oxidation of fatty acids (Acyl CoA oxidase), and energy dissipation (Uncoupling protein 2, UCP-2) [59,60]. The high levels of adiponectin with the percentage of adipose tissue in the treatment group clearly denotes an inverse relationship, which helps maintain muscle and liver oxidation of fatty acids. Likewise, the levels of E-selectin, cHDL, cLDL, and blood pressure of the group treated with pomegranate juice evidence that the treatment, as shown by increased adiponectin levels, decreased cardiovascular risk factors [61,62].

\subsection{Markers of Inflammation and Cytokines in Adipose Tissue}

Since the effect of juice on inflammation markers has only been reported in serum, in this study, the effect was determined directly in retroperitoneal adipose tissue, which is metabolically more active than the epididymal tissue. The changes in the levels of leptin, insulin, MCP-1, and PAI-1 due to the administration of pomegranate juice are shown in Figure 1. The adipose tissue of the group of animals treated with JP was 15\% lower 
compared to the adipose tissue developed in the animals of the HD group, and although there was no difference in leptin levels, adiponectin levels were increased (Figure 1A). In view of the fact that leptin is secreted by adipocytes and that plasma leptin concentration is known to be proportional to the volume of adipose tissue, it would be expected that blood leptin levels would be lower in the JP group, representing an advantage as due to this relationship, the regulation of the energy balance is promoted, thereby suppressing food intake and promoting energy expenditure according to nutritional status [63-65].

Insulin levels increased by $41 \%$ in the group treated with pomegranate juice compared to the HD group without insulin resistance, while the SD and HD groups did not show any difference (Figure 1B). This is important since although there is no difference in insulin levels between the SD and HD groups, the glucose levels in the HD group were increased, while in the JP group they were adequately reduced since the main function of insulin is to keep glucose levels at normal intervals and to promote its uptake in adipose tissue, muscle, and the liver. Therefore, the results of pomegranate juice suggest an efficient glucose uptake in adipose tissue, likely by some mechanism of protection of the $\beta$-pancreatic cells.

In the JP group (Figure 1C), PAI-1 decreased by $25 \%$ compared to the HD group, even though it did not reach the levels of the SD group, which suggests an anti-atherosclerotic and antithrombotic effect benefiting the cardiovascular system since high levels of PAI-1 generate the development of fibrin deposits, so that fibrin enhances fibrosis, atherogenesis, and arterial thrombosis [66].

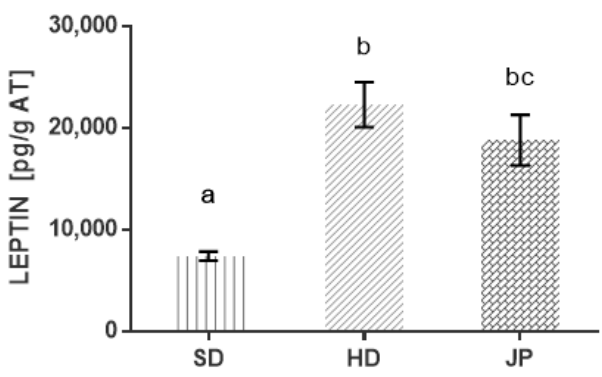

c

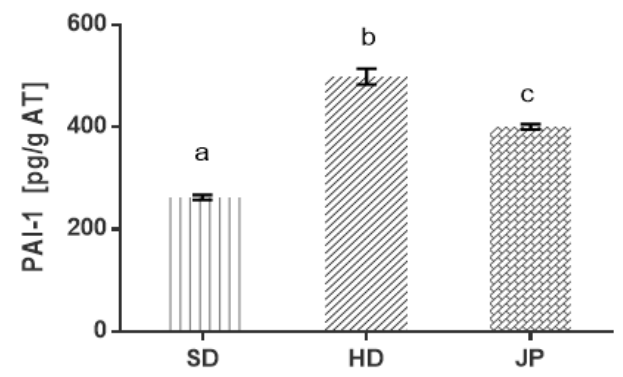

B

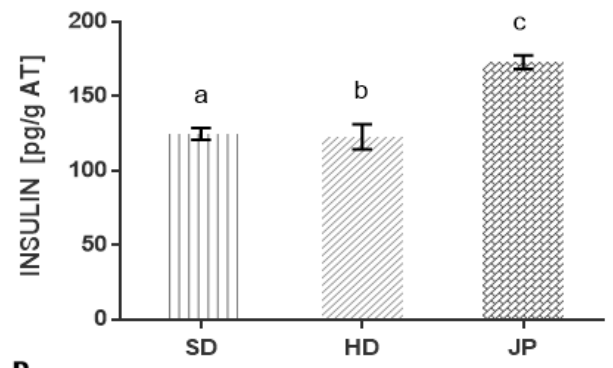

D

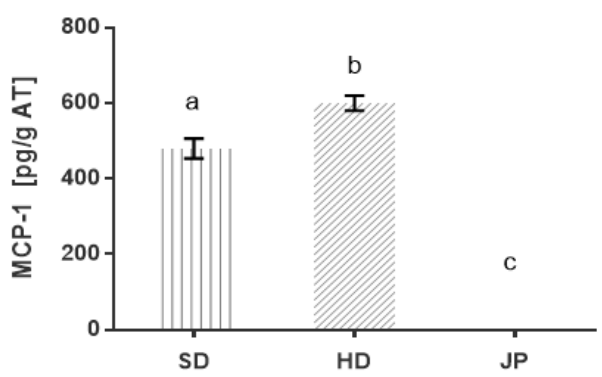

Figure 1. Effect of the polyphenols present in pomegranate juice on markers of inflammation in adipose tissue. (A) Leptin, (B) insulin, (C) plasminogen activator inhibitor-1(PAI-1), (D) monocyte chemoattractant protein-1(MCP-1); standard diet (SD); high-fat diet (HD); high-fat diet + pomegranate juice (JP). Statistical analysis was determined using the non-parametric Mann-Whitney-Wilcoxon test with a significance level of $p \leq 0.05$. Different letters $\left({ }^{a},{ }^{b}\right.$ and $\left.{ }^{c}\right)$ represent the significant statistical difference between the groups.

TNF- $\alpha$ regulates the increase in PAI- 1 in adipocytes through the TNF- $\alpha$ signaling pathway linked to TNFR1, which involves the activation of p42/p44, PKC, p38, PI3K, $\mathrm{NF} \kappa \mathrm{B}$, and reactive oxygen species (ROS) production [67], increasing inflammation.

According to the low levels of TNF- $\alpha$ and PAI-1 in the JP group, this relationship leads to a lower risk of vascular complications $[68,69]$. As is well described in various studies, MCP-1 is the monocyte chemoattractant protein with proinflammatory effects, 
whose levels are increased in response to tissue damage. Regarding the quantified MCP-1 levels (Figure 1D), they were high for the HD control group, whereas this marker was not detected with the pomegranate juice treatment. It is possible that the pomegranate juice could regulate the expression of the gene and consequently did not express the protein by the action of the phenolic compounds present (anthocyanins, ellagic acid); thus, it decreased the RI, the inhibition of the expression of Glucose Transporter Protein 4 (GLUT-4), Peroxisome Proliferator Activated Receptors $\gamma$ (PPAR $\gamma)$, and the fatty acid transporter protein (FATP) [70].

There are studies with obese rodents and humans that show that circulating MCP-1, as well as the MCP-1 ligand (motif ligand 2 (part of a protein sequence that is associated with a particular biological function)) C-C, CCL2, or MCP-1), are increased in proportion to the level of obesity, and they decrease after treatment with thiazolidinediones [71,72]. Efforts have been made to inhibit MCP-1 overproduction and to reduce obesity-related comorbidities, such as insulin resistance and type 2 diabetes. In particular, some treatments of phenolic compounds have been reported to reduce MCP-1 levels, for example, $11 \mathrm{~g}$ of bamboo leaf ethanolic extract was used for 6 months in C57BL/6J mice, reducing the circulating MCP-1 levels by $49 \%$. In another study, they used capsaicin $(0.015 \%)$ for 10 weeks in obese mice, decreasing the expression of MCP-1 mRNA in adipose tissue.

Procyanidins extracted from grape seeds evaluated in human adipocytes (SGBS) and macrophages (THP-1) reduced the expression of MCP-1 and IL- 6 by inhibiting the translocation of the NF- $\mathrm{kB}$ to the nucleus in both cell lines, thus improving the production of adiponectin [73-76].

In this study, proinflammatory cytokines (IL- $\alpha$, IL- $\beta$, IL- 6 and TNF- $\alpha$ ) that promote insulin resistance at the post-receptor level in the adipose tissue through the PI3K pathway and are involved in both metabolic regulation and inflammatory processes were evaluated [77-79]. In addition, anti-inflammatory cytokines, such as interleukin 10 (IL-10) and adiponectin, were evaluated.

The results in Figure 2A,D show that in the obese group (HD) there was no change in the levels of IL- $1 \alpha$, and IL- 6 compared to the healthy group (SD); in contrast, the levels of IL- $1 \beta$ and TNF- $\alpha$ (Figure 2B,C) in the HD group increased by $48 \%$ and $46 \%$, respectively. In addition, the IL-10 levels (Figure $2 \mathrm{E}$ ) decreased by $39 \%$ compared to the SD group. Deregulation of these cytokines demonstrates a state of inflammation induced by a hypercaloric diet. Since proinflammatory cytokines in adipose tissue are expressed mainly by macrophages [79], in obesity and diabetes, lipid accumulation has been reported to trigger an immune response related to macrophage activation by polarizing to an M1 profile [80].

On the other hand, the JP group that was treated with pomegranate juice had reduced IL- $1 \alpha$ levels by $9 \%$, IL- 6 by $40 \%$, IL- $1 \beta$ by $44 \%$, and TNF- $\alpha$ by $25 \%$, whose values were very similar to those of the SD group. These results show that pomegranate juice regulates the production of proinflammatory cytokines by induction, possibly in the phenotypic change of macrophages from an M1 to M2 profile [81]. The regulation of this response would be expected to be mediated by the production of anti-inflammatory cytokines, such as IL-10, which, in obesity, has elevated levels as a homeostatic mechanism in response to a state of inflammation [82-84]. However, IL-10 levels in the JP group decreased by $20 \%$ compared to the HD group; even though the increase was not observed in this model of IL-10, it was observed that adiponectin was increased in response to treatment. The regulation of proinflammatory cytokines in the JP group may also be associated with the effect of polyphenols (anthocyanins and ellagic acid) present in pomegranate juice by interfering with the signaling pathways that lead to the production of these cytokines, with an antagonistic effect of the receptors that signal its production and/or blocking translocation to the nucleus of transcription factors, such as nuclear factor $\mathrm{kB}(\mathrm{NF}-\mathrm{kB})$, preventing the expression of proinflammatory genes (TNF- $\alpha$, IL-6 and IL-1) $[85,86]$.

Different studies report that polyphenols promote health through multiple signaling pathways (such as lipid anabolism/catabolism pathways and apoptotic pathways) [87]. 
A

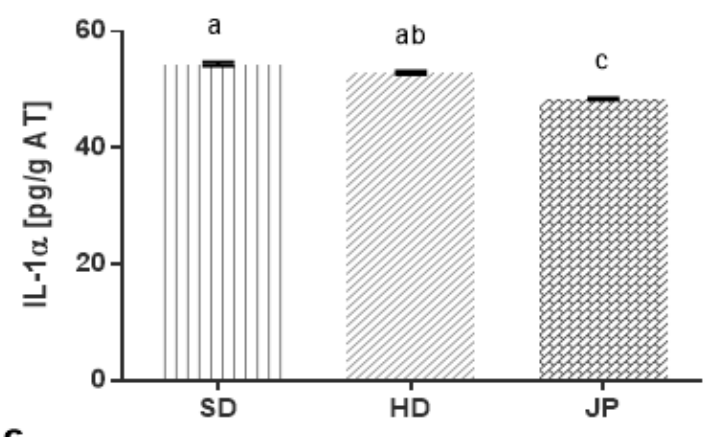

C

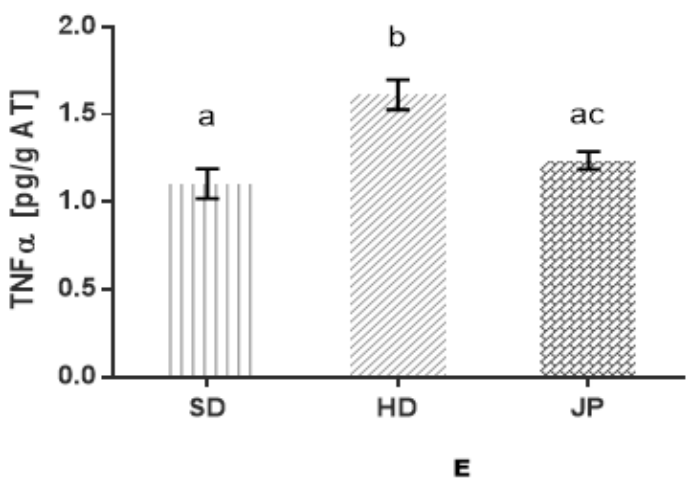

B
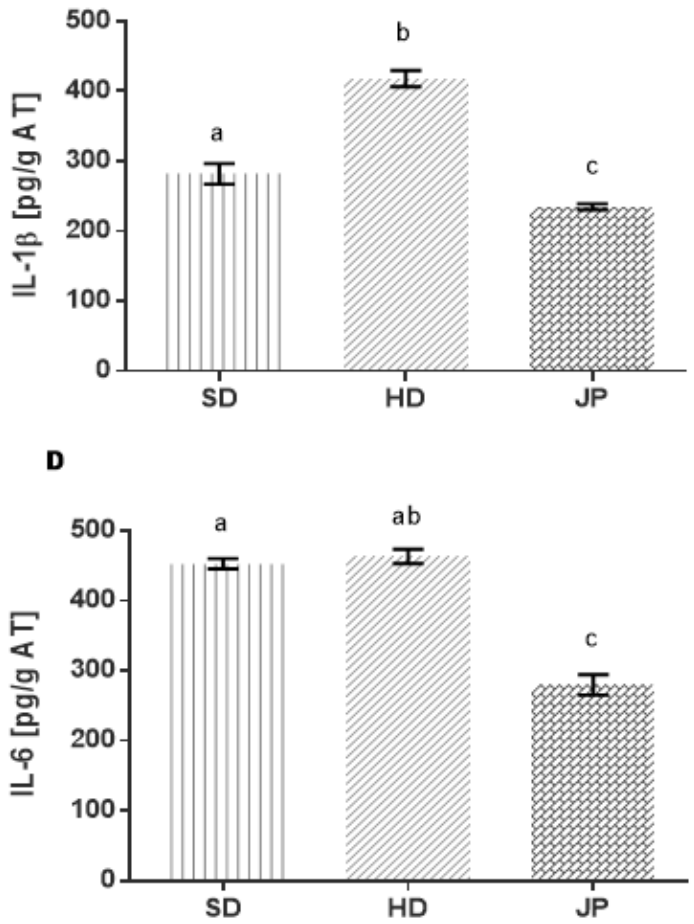

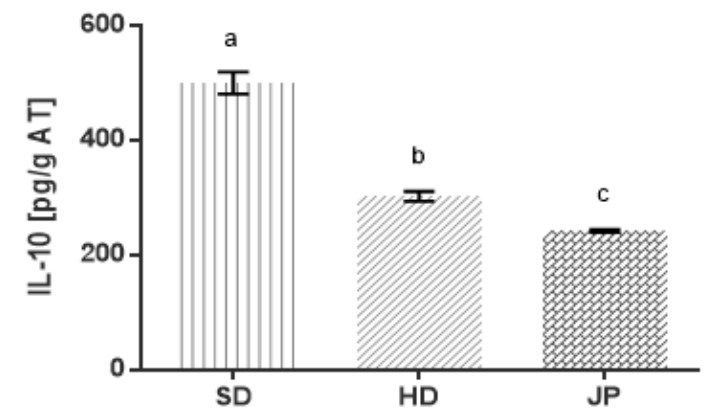

Figure 2. Effect of the polyphenols present in pomegranate juice on the regulation of interleukins in adipose tissue. (A) Interleukin $1 \alpha$ (IL-1 $\alpha)$; (B) interleukin $1 \beta$ (IL-1 $\beta)$; (C) tumor necrosis factor (TNF- $\alpha)$; (D) interleukin 6 (IL-6); (E) interleukin 10 (IL-10). Groups are abbreviated as standard diet (SD); high-fat diet (HD); high-fat diet + pomegranate juice (JP) group with treatment. Statistical analysis was determined by using the non-parametric Mann-Whitney-Wilcoxon test with a significance level of $p \leq 0.05$. Different letters $\left({ }^{a},{ }^{b}\right.$ and ${ }^{c}$ ) represent the significant statistical difference between the groups.

Pomegranate juice suppresses TNF- $\alpha$-induced COX-2 expression, which in turn activates the NF- $\mathrm{kB}$ and Akt pathway, suggesting that the anthocyanins and flavones present in pomegranate juice may be responsible [88]. The metabolites products derived from the digestion in the gastrointestinal tract of cyanidine 3-glucoside, such as protecatecuic acid, inhibit the production of IL-6, TNF- $\alpha$, IL- $\beta$ and prostaglandin E2 (PGE2), suppressing the nuclear factor-kB and the extracellular signal-regulated kinase (ERK) [89]. Purple corn containing cyanidin 3-glucoside (C3G) works as a powerful antioxidant in vivo (C57BL/6 male mice), whose administration with $2 \mathrm{~g} / \mathrm{Kg}$ per day for 12 weeks suppresses proinflammatory cytokines as TNF- $\alpha$ in the acute process of inflammation [90]. On the other hand, it is likely that pomegranate juice favors autophagy, thus explaining the decrease in IL- $1 \beta$ since it has been shown that its production is very finely regulated by autophagy, so that molecules are negatively regulated in this way and involved in the production of IL-1 $\beta$ [65].

Pomegranate juice demonstrates its potential as a nutraceutical due to its complex composition of phytochemicals (hydrolysable tannins, anthocyanins, and ellagic acid) with 
an immunoregulatory and therapeutic effect on cardiovascular risks, maintaining normal pressure levels due to its antioxidant and protective power since it generates the balance between cHDL and CLDL. It reduces damage to the endothelium by attenuating the levels of sE-S, preventing its progression to atherosclerosis that is generated by obesity.

Likewise, it has a regulatory effect on the immune system, reducing cytokine levels and proinflammatory markers (TNF- $\alpha, \mathrm{IL}-1 \alpha, \mathrm{IL}-1 \beta, \mathrm{IL}-6)$ and increasing the levels of adiponectin (anti-inflammatory interleukin), in addition to being a possible MCP-1 inhibitor, promoting the good functioning of adipose tissue. Hence, we suggest the promotion of the use of pomegranate juice as an adjuvant and/or drug substitute to help improve the deteriorated state of health due to obesity-generated pathophysiology (chronic low-grade inflammation), metabolic syndrome, and type 2 diabetes. Our results demonstrate that pomegranate juice reduces the concentration of inflammation markers, the mechanisms for which this occurs are not known, so it is important to know, among others, how pomegranate juice modulates the expression of genes associated with inflammation of adipose tissue in obese. Likewise, clinical trials are needed to evaluate the effect of pomegranate juice on inflammation markers and gene expression associated with inflammation in the plasma of obese people in order to relate them to preclinical studies. It is thus convenient to evaluate the effect of pomegranate juice compared to that of statins in hypertensive people since the results of this study show a significant decrease in blood pressure. An understanding of the mechanisms by which MCP-1 inhibition occurs, as well as the increase in the von Willebrand factor is required. Although this study was conducted in an animal model, the results are promising and could be a guideline for further studies in human clinical trials to establish the potential advantage to use derivatives of pomegranate as a treatment to metabolic diseases.

\section{Conclusions}

This study provides relevant findings in the field of metabolic diseases. The hallmark of obesity is the accumulation of dysfunctional adipose tissue, which induces a plethora of complications that can cause low-grade chronic systemic inflammation. Together, these results emphasize that pomegranate juice reduces some of the major cytokines related with the low-grade inflammation and parameters associated with cardiovascular risk in obesity. Since in obesity adipose tissue is the niche for cells involved in the production of several bioactive molecules that promote chronic inflammation, a remarkable success of this work is that the effect of pomegranate juice was analyzed in this tissue. However, extensive studies are necessary in order to understand the plausible active compound involved in the positive effect of pomegranate juice, as well as the molecular mechanism implicated in the homeostatic inflammation promoted by this nutraceutical. Nevertheless, the consumption of pomegranate juice could represent a potential alternative as an adjuvant in the treatment of obesity.

Author Contributions: M.M.M.-M.: investigation, analysis, writing, and editing; B.E.G.-P.: review and editing; C.A.R.-L.: methodology, supervision; M.d.R.T.-B.: conceptualization, funding, supervision; C.O.-P.: methodology, supervision; I.I.L.-T.: investigation; M.E.J.-F.: conceptualization, funding acquisition, validation, writing - review and editing. All authors have read and agreed to the published version of the manuscript.

Funding: This work was financially supported through the project SIP-IPN 20200734; SIP20210177. The first author thanks the Mexican National Council for Science and Technology (CONACYT) for the Ph.D. grant provided.

Institutional Review Board Statement: The study was approved by the BioEthics Committee of the Escuela Nacional de Medicina y Homeopatía CBE/005/2021.

Informed Consent Statement: Not applicable.

Conflicts of Interest: The authors declare no conflict of interest. 


\section{References}

1. Bulló, M.; Casas-Agustench, P.; Amigó-Correig, P.; Aranceta, J.; Salas-Salvadó, J. Inflammation, obesity and comorbidities: The role of diet. Public Health Nutr. 2007, 10, 1164-1172. [CrossRef]

2. Jarolimova, J.; Tagoni, J.; Stern, T.A. Obesity: Its epidemiology, comorbidities, and management. Prim. Care Companion CNS Disord. 2013, 15. [CrossRef] [PubMed]

3. Han, J.M.; Levings, M.K. Immune regulation in obesity-assosiated adipose inflammation. J. Immunol. 2013, 191, 527-532. [CrossRef]

4. Tsoupras, A.; Lordan, R.; Zabetakis, I. Inflammation, not Cholesterol, Is a Cause of Chronic Disease. Nutrients 2018, 10, 604. [CrossRef] [PubMed]

5. Saltiel, A.R.; Olefsky, J.M. Inflammatory mechanims linking obestity and metabolic disease. J. Clin. Investig. 2017, 127, 1-4. [CrossRef]

6. Ouchi, N.; Parker, J.L.; Lugus, J.J.; Walsh, K. Adipokines in inflammation and metabolic disease. Nat. Rev. Immunol. 2011, 11, 85-97. [CrossRef]

7. Lima Vieira, R.A.; Nascimiento de Freitas, R.; Pinheiro, V. Adhesion molecules and chemokines: Relation to anthropometric, body composition, biochemical and dietary variables. Nutr. Hosp. 2014, 30, 223-236.

8. Moreno Esteban, B.; Foz Sala, M. La Obesidad Como Factor de Riesgo Cardiovascular. Obesidad y Riesgo Cardiovascular; Estudio Dorica; Médica Panamericana: Madrid, Spain, 2004; pp. 49-60.

9. Crespo, I.; García-Mediavilla, M.V.; Gutiérrez, B.; Sánchez-Campos, S.; Tuñón, M.J.; González-Gallego, J. A comparison of the effects of kaempferol and quercetin on cytokine-induced pro-inflammatory status of cultured human endothelial cells. Br. J. Nutr. 2008, 100, 968-976. [CrossRef] [PubMed]

10. Yamauchi, T.; Kadowaki, T. Adiponectin receptor as a key player in healthy longevity and obesity-related diseases. Cell Metab. 2013, 17, 185-196. [CrossRef]

11. Lovren, F.; Teoh, H.; Verma, S. Obesity and Atherosclerosis: Mechanistic Insights. Can. J. Cardiol. 2015, 31, 177-183. [CrossRef] [PubMed]

12. Nakayama, T.; Wang, Z. Inflammation, a link between obesity and cardiovascular disease. Mediat. Inflamm. 2010. [CrossRef]

13. Arnold, N.; Lechner, K.; Shapiro, M.D.; Koening, W. Inflammation and Cardiovascular Disease. Eur. Cardiol. Rev. 2021, 16, e20. [CrossRef] [PubMed]

14. Banihani, S.; Swedan, S.; Alguraan, Z. Pomegranate and type 2 diabetes. Nutr. Res. 2013, 33, 341-348. [CrossRef] [PubMed]

15. $\mathrm{Wu}, \mathrm{S}$.; Tian, L. Diverse phytochemicals and bioactivities in the ancient fruit and modern functional food pomegranate (punica granatum). Molecules 2017, 22, 1606. [CrossRef] [PubMed]

16. Faria, A.; Calhau, C. Pomegranate in human health: An overview. Bioact. Foods Promot. Health 2010, 551-563. [CrossRef]

17. Khomich, L.M.; Perova, I.B.; Eller, K.I. Pomegranate juice nutritional profile. Vopr. Pitan. 2019, 88, 80-92.

18. Hou, C.; Zhang, W.; Li, J.; Du, L.; Lv, O.; Zhao, S.; Li, J. Beneficial Effects of Pomegranate on Lipid Metabolism in Metabolic Disorders. Mol. Nutr. Food Res. 2019, 63, 1-12. [CrossRef]

19. De Nigris, F.; Williams-Ignarro, S.; Sica, V.; Lerman, L.O.; D’Armiento, F.P.; Byrns, R.E.; Napoli, C. Effects of a Pomegranate Fruit Extract rich in punicalagin on oxidation-sensitive genes and eNOS activity at sites of perturbed shear stress and atherogenesis. Cardiovasc. Res. 2007, 73, 414-423. [CrossRef]

20. Sohrab, G.; Roshan, H.; Ebrahimof, S.; Nikpayam, O.; Sotoudeh, G.; Siasi, F. Effects of pomegranate juice consumption on blood pressure and lipid profile in patients with type 2 diabetes: A single-blind randomized clinical trial. Clin. Nutr. ESPEN 2019, 29, 30-35. [CrossRef]

21. Estrada-Luna, D.; Carreón-Torres, E.; Bautista-Pérez, R.; Betanzos-Cabrera, G.; Dorantes-Morales, A.; Luna-Luna, M.; VargasBarrón, J.; Mejía, A.M.; Fragoso, J.M.; Carvajal-Aguilera, K.; et al. Microencapsulated pomegranate reverts high-density lipoprotein (hdl)-induced endothelial dysfunction and reduces postprandial triglyceridemia in women with acute coronary syndrome. Nutrients 2019, 11, 1710. [CrossRef]

22. Giusti, M.; Wrolstad, R.E. Characterization and Measurement of Anthocyanins by UV-visible Spectroscopy. Curr. Protoc. Food Anal. Chem. 2001, 1-13. [CrossRef]

23. Herald, T.J.; Gadgil, P.; Tilley, M. High-throughput micro plate assays for screening flavonoid content and DPPH-scavenging activity in sorghum bran and flour. J. Sci. Food Agric. 2012, 92, 2326-2331. [CrossRef]

24. Li, X.; Wasila, H.; Liu, L.; Yuan, T.; Gao, Z.; Zhao, B.; Ahmad, I. Physicochemical characteristics, polyphenol compositions and antioxidant potential of pomegranate juices from 10 Chinese cultivars and the environmental factors analysis. Food Chem. 2015, 175, 575-584. [CrossRef]

25. Rabadan-Chávez, G.; Quevedo-Corona, L. Cocoa powder, cocoa extract and epicatechin attenuate hypercaloric diet-induced obesity through enhanced $\beta$-oxidation and energy expenditure in white adipose tissue. J. Funct. Foods 2016, 20, 54-67. [CrossRef]

26. Grasa-López, A.; Miliar-garcía, Á.; Quevedo-corona, L.; Paniagua-castro, N.; Escalona-cardoso, G.; Reyes-maldonado, E.; Jaramillo-Flores, M.E. Undaria pinnatifida and Fucoxanthin Ameliorate Lipogenesis and Markers of Both Inflammation and Cardiovascular Dysfunction in an Animal Model of Diet-Induced Obesity. Mar. Drugs 2016, 14, 148. [CrossRef] [PubMed]

27. Mphahlele, R.R.; Fawole, O.A.; Mokwena, L.M.; Opara, U.L. Effect of extraction method on chemical, volatile composition and antioxidant properties of pomegranate juice. S. Afr. J. Bot. 2016, 103, 135-144. [CrossRef] 
28. Fischer, U.A.; Carle, R.; Kammerer, D.R. Identification and quantification of phenolic compounds from pomegranate (Punica granatum L.) peel, mesocarp, aril and differently produced juices by HPLC-DAD-ESI/MSn. Food Chem. 2011, 127, 807-821. [CrossRef]

29. Labbé, M.; Ulloa, P.A.; Lopez, F.; Saenz, C.; Pena, A.; Salazar, F.N. Characterization of chemical compositions and bioactive compounds in juices from pomegranates ('Wonderful', 'Chaca' and 'Codpa') at different maturity stages. Chil. J. Agric. Res. 2016, 76, 479-486. [CrossRef]

30. Russo, M.; Fanali, C.; Tripodo, G.; Dugo, P.; Muleo, R.; Dugo, L.; De Gara, L.; Mondello, L. Analysis of phenolic compounds in different parts of pomegranate (Punica granatum) fruit by HPLC-PDA-ESI/MS and evaluation of their antioxidant activity: Application to different Italian varieties. Anal. Bioanal. Chem. 2018, 410, 3507-3520. [CrossRef]

31. Russo, M.; Cacciola, F.; Arena, K.; Mangraviti, D.; de Gara, L.; Dugo, P.; Mondello, L. Characterization of the polyphenolic fraction of pomegranate samples by comprehensive two-dimensional liquid chromatography coupled to mass spectrometry detection. Nat. Prod. Res. 2019, 34, 39-45. [CrossRef] [PubMed]

32. Sentandreu, E.; Cerdán-Calero, M.; Sendra, J.M. Phenolic profile characterization of pomegranate (Punica granatum) juice by high-performance liquid chromatography with diode array detection coupled to an electrospray ion trap mass analyzer. J. Food Compos. Anal. 2013, 30, 32-40. [CrossRef]

33. Galván-Meléndez, M.F.; Lares-Bayona, E.F.; Quintanar-Escorza, M.A.; de la Ascención Carrera-Gracia, M.; Torres-Castorena, A. Concentraciones de leptina y su correlación con los componentes del síndrome metabólico y con el índice de masa corporal. Revista Biomédica 2014, 25, 23-30.

34. Ahmed, M.M.; Samir, E.S.A.; El-Shehawi, A.M.; Alkafafy, M.E. Anti-obesity effects of Taif and Egyptian pomegranates: Molecular study. Biosci. Biotechnol. Biochem. 2015, 79, 598-609. [CrossRef]

35. Simón, E.; Del Barrio, A.S. Leptina y obesidad. Anales del Sistema Sanitario de Navarra 2002, 25, 53-64. [PubMed]

36. Miguelsanz, M.J.P.; Parra, W.C.; Moreiras, G.V.; Garaulet, M. Distribución regional de la grasa corporal: Uso de Técnicas de Imagen como Herramienta de Diagnóstico Nutricional. Nutr. Hosp. 2010, 25, 207-223.

37. Ramos-Ibáñez, N. Tejido adipose intra-abdominal: Crecimiento, evaluación y su asociación con el Desarrollo de problemas metabólicos en niños y adolescents. Boletín Médico Hospital Infantil México 2009, 66, 492-501.

38. Murphy, J.; Bacon, S.L.; Morais, J.A.; Tsoukas, M.A.; Santosa, S. Intra-Abdominal Adipose Tissue Quantification by Alternative Versus Reference Methods: A Systematic Review and Meta-Analysis. Obesity 2019, 27, 1115-1122. [CrossRef]

39. Mertens, I.L.; Van Gaal, L.F. Overweight, obesity, and blood pressure: The effects of modest weight reduction. Obes. Res. 2000, 8, 270-278. [CrossRef] [PubMed]

40. Valido Díaz, A.; Romero Borges, R.; Bernal Llerena, T.; Fimia Duarte, R.; Iannacone, J. Biomodelo De Hipertensión Arterial En Ratas Wistar Administradas Con Solución Salina Al 10\%. Biotempo 2018, 15, 75-82. [CrossRef]

41. Flores Chávez, P.L.; Santos Martínez, L.E.; Martínez Memije, R.; Cortés Tenorio, S.; Sánchez Torres, G.; Vázquez Infante, O.I. Confiabilidad de la presion arterial sistémica determinada por un método no invasivo en ratas normotensas. Revista Instituto Nacional Enfermedades Respiratorias 2007, 20, 247-254.

42. Barber Fox, M.O.; Barber Gutiérrez, E.; Fox Pascual, M. Hipertensión arterial experimental por medio del uso de un bloqueador competitive de angiotensina II. Revista Cubana Investigaciones Biomédicas 2006, 25, 1.

43. Christerson, M. Anthocyanins and their effects on blood pressure. Fac. Nat. Res. Agric. Sci. Dev. Food Sci. 2016, $439,1-23$.

44. Jordão, J.B.R.; Porto, H.K.P.; Lopes, F.M.; Batista, A.C.; Rocha, M.L. Protective Effects of Ellagic Acid on Cardiovascular Injuries Caused by Hypertension in Rats. Planta Med. 2017, 83, 830-836.

45. Ali, K.M.; Wonnerth, A.; Huber, K.; Wojta, J. Cardiovascular disease risk reduction by raising HDL cholesterol—Current therapies and future opportunities. Br. J. Pharmacol. 2012, 167, 1177-1194. [CrossRef]

46. Seravalle, G.; Grassi, G. Obesity and hypertension. Pharmacol. Res. 2017, 122, 1-7. [CrossRef] [PubMed]

47. Hutcheson, J. Adipokines influence the inflammatory balance in autoimmunity. Cytokine 2015, 75, 272-279. [CrossRef] [PubMed]

48. Danesi, F.; Ferguson, L.R. Could pomegranate juice help in the control of inflammatory diseases? Nutrients 2017, 9, 958. [CrossRef]

49. Millar, C.L.; Duclos, Q.; Blesso, C.N. Effects of Dietary Flavonoids on Reverse Cholesterol Transport, HDL Metabolism, and HDL Function. Adv. Nutr. Int. Rev. J. 2017, 8, 226-239. [CrossRef] [PubMed]

50. Karlsen, A.; Retterstøl, L.; Laake, P.; Paur, I.; Kjølsrud-Bøhn, S.; Sandvik, L.; Blomhoff, R. Anthocyanins Inhibit Nuclear Factor-kB Activation in Monocytes and Reduce Plasma Concentrations of Pro-Inflammatory Mediators in Healthy Adults. J. Nutr. 2007, 137, 1951-1954. [CrossRef]

51. Masana, L.; Ibarretxe, D.; Plana, N. Máxima reducción de colesterol unido a lipoproteínas de baja densidad alcanzable con combinaciones farmacológicas. Cuando 50 más 20 suma 60. Revista Española Cardiología 2016, 69, 342-343. [CrossRef]

52. Jones, P.; Kafonek, S.; Laurora, I.; Hunninghake, D. Comparative dose efficacy study of atorvastatin versus simvastatin, pravastatin, lovastatin, and fluvastatin in patients with hypercholesterolemia (The Curves Study). Am. J. Cardiol. 1998, 81, 582-587. [CrossRef]

53. Alfonso, J.E.F.; Ariza, I.D.S. Elevando el colesterol HDL: ¿Cuál es la mejor estrategia? Revista Associacao Medica Brasileira 2008, 54, 369-376. [CrossRef] [PubMed]

54. Barreiro, O.; Sánchez-Madrid, F. Bases moleculares de las interacciones leucocito-endotelio durante la respuesta inflamatoria. Revista Española Cardiología 2009, 62, 552-562. [CrossRef] 
55. Newman, C.B.; Preiss, D.; Tobert, J.A.; Jacobson, T.A.; Page, R.L.; Goldstein, L.B.; Chin, C.; Tannock, L.R.; Miller, M.; Raghuveer, G.; et al. Statin Safety and Associated Adverse Events A Scientific Statement from the American Heart Association. Arterioscler. Thromb. Vasc. Biol. 2019, 39, E38-E81. [CrossRef]

56. Engin, A. Adiponectin-Resistance in obesity. Obes. Lipotoxicity 2017, 960, 221-236.

57. Gragnano, F.; Sperlongano, S.; Golia, E.; Natale, F.; Bianchi, R.; Crisci, M.; Fimiani, F.; Pariggiano, I.; Vincenzo, D.; Carbone, A.; et al. The role on von Willebrand Factor in Vascular Inflammation: From Pathogenesis to Targeted Therapy. Mediat. Inflamm. 2017, 2017. [CrossRef]

58. Wang, D.; Özen, C.; Abu-Reidah, I.M.; Chigurupati, S.; Patra, J.K.; Horbanczuk, J.O.; Jóźwi, A.; Tzvetkov, N.T.; Uhrin, P.; Atanasov, A.G. Vasculoprotective effects of pomegranate (Punica granatum L.). Front. Pharmacol. 2018, 9, 1-15. [CrossRef]

59. Achari, A.E.; Jain, S.K. Adiponectin, a therapeutic target for obesity, diabetes, and endothelial dysfunction. Int. J. Mol. Sci. 2017, 18, 1321. [CrossRef]

60. Elissondo, N.; Rosso, L.G.; Maidana, P.; Brites, F. Bioquímica Clínica Actualización Adiponectina: Una adipocitoquina con múltiples funciones protectoras* Adiponectin: An adipocytokine with multiple protective functions. Acta Bioquímica Clínica Latinoamerica 2008, 24, 17-33.

61. Domínguez Reyes, C. Adiponectina: El tejido adipose más allá de la reserve de energía. Revista Endocrinología Nutrición 2007, 15, 149-155.

62. Nagaraju, G.P.; Rajitha, B.; Aliya, S.; Kotipatruni, R.P.; Madanraj, A.S.; Hammond, A.; Park, D.; Chigurupati, S.; Alam, A.; Pattnaik, S. The role of adiponectin in obesity-associated female-specific carcinogenesis. Cytokine Growth Factor Rev. 2016, 31, 37-48. [CrossRef]

63. Morales Clavijo, M.; Carvajal Garcés, C.F. Obesity and leptin resistance. Gac. Med. Bol. 2010, 33, $63-68$.

64. Farr, O.M.; Gavrieli, A.; Mantzoros, C.S. Leptin applications in 2015: What have we learned about leptin and obesity? Curr. Opin. Endocrinol. Diabetes Obes. 2015, 22, 353-359. [CrossRef]

65. Zhang, Y.; Sowers, J.R.; Ren, J. Targeting autophagy in obesity: From pathophysiology to management. Nat. Rev. Endocrinol. 2018, 14, 356-376. [CrossRef] [PubMed]

66. Ploplis, V. Effects of Altered Plasminogen Activator Inhibitor-1 Expression on Cardiovascular Disease. Curr. Drug Targets 2011, 12, 1782-1789. [CrossRef] [PubMed]

67. Cawthorn, W.P.; Sethi, J.K. TNF- $\alpha$ and adipocyte biology. FEBS Lett. 2008, 582, 117-131. [CrossRef]

68. Eriksson, P.; Reynisdottir, S.; Lönnqvist, F.; Stemme, V.; Hamsten, A.; Amer, P. Adipose tissue secretion of plasminogen activator inhibitor-1 in non-obese and obese individuals. Diabetología 1998, 41, 65-71. [CrossRef] [PubMed]

69. Nolasco, M.; Salcedo, M.; Vázquez-Ortiz, G. Activación del Sistema Plasminógeno-Plasmina y el Papel de PAI-1 en Patologías Humanas. Revista Cancerologia. 2007, 2, 2.

70. Bastarrachea, R.A.; López-Alvarenga, J.C.; Bolado-garcía, V.E.; Téllez-mendoza, J.; Comuzzie, A.G. Obesidad y resistencia a la insulina. Gaceta Médica México 2007, 143, 505-512.

71. Bruun, J.M.; Lihn, A.S.; Pedersen, S.B.; Richelsen, B. Monocyte chemoattractant protein-1 release is higher in visceral than subcutaneous human adipose tissue (AT): Implication of macrophages resident in the AT. J. Clin. Endocrinol. Metab. 2005, 90, 2282-2289. [CrossRef]

72. Mohanty, P.; Aljada, A.; Ghanim, H.; Hofmeyer, D.; Tripathy, D.; Syed, T.; Al-Haddad, W.; Dhindsa, S.; Dandona, P. Evidence for a potent antiinflammatory effect of rosiglitazone. J. Clin. Endocrinol. Metab. 2004, 89, 2728-2835. [CrossRef] [PubMed]

73. Panee, J. Monocyte Chemoattractant Protein 1 (MCP-1) in obesity and diabetes. Cytokine 2012, 60, 1-12. [CrossRef] [PubMed]

74. Higa, J.K.; Liu, W.; Berry, M.J.; Panee, J. Supplement of bamboo extract lowers serum monocyte chemoattractant protein-1 concentration in mice fed a diet containing a high level of saturated fat. Br. J. Nutr. 2011, 106, 1810-1813. [CrossRef] [PubMed]

75. Kang, J.H.; Tsuyoshi, G.; Han, I.S.; Kawada, T.; Kim, Y.M.; Yu, R. Dietary capsaicin reduces obesity-induced insulin resistance and hepatic steatosis in obese mice fed a high-fat diet. Obesity 2010, 18, 780-787. [CrossRef] [PubMed]

76. Chacón, M.R.; Ceperuelo-Mallafré, V.; Maymó-Masip, E.; Mateo-Sanz, J.M.; Arola, L.; Guitiérrez, C.; Fernández-Real, J.M.; Ardèvol, A.; Simón, I.; Vendrell, J. Grape-seed procyanidins modulate inflammation on human differentiated adipocytes in vitro. Cytokine 2009, 47, 137-142. [CrossRef]

77. Kang, Y.E.; Kim, J.M.; Joung, K.H.; Lee, J.H.; You, B.R.; Choi, M.J.; Ryu, M.J.; Ko, Y.B.; Lee, A.M.; Lee, J.; et al. The roles of adipokines, proinflammatory cytokines, and adipose tissue macrophages in obesity-associated insulin resistance in modest obesity and early metabolic dysfunction. PLoS ONE 2016, 11, e0154003. [CrossRef]

78. Ruan, H.; Hacohen, N.; Golub, T.R.; Parijs, L.; Van Lodish, H.F. Tumor Necrosis Factor- $\alpha$ Suppresses Adipocyte-Specific Genes and Activates Expression of Preadipocyte Genes in 3T3-L1 Adipocytes. Cell Rep. 2002, 1, 1319-1336.

79. Weisberg, S.P.; Leibel, R.L.; Anthony, W.F., Jr.; Weisberg, S.P.; Mccann, D.; Ferrante, A.W. Obesity is associated with macrophage accumulation in adipose tissue. Find the latest version: Obesity is associated with. J. Clin. Investig. 2003, 112, 1796-1808. [CrossRef]

80. Russo, L.; Lumeng, C.N. Properties and functions of adipose tissue macrophages in obesity. Immunology 2018, $155,407-417$. [CrossRef] [PubMed]

81. Aharoni, S.; Lati, Y.; Aviram, M.; Fuhrman, B. Pomegranate juice polyphenols induce a phenotypic switch in macrophage polarization favoring a M2 anti-inflammatory state. BioFactors 2015, 41, 44-51. [CrossRef] 
82. Bradley, R.L.; Fisher, F.M.; Maratos-Flier, E. Dietary fatty acids differentially regulate production of TNF- $\alpha$ and IL-10 by murine 3T3-L1 adipocytes. Obesity 2008, 16, 938-944. [CrossRef]

83. Fain, J.N. Release of inflammatory mediators by human adipose tissue is enhanced in obesity and primarily by the nonfat cells: A review. Mediat. Inflamm. 2010, 2010. [CrossRef] [PubMed]

84. Fain, J.N.; Madan, A.K.; Hiler, M.L.; Cheema, P.; Bahouth, S.W. Comparison of the release of adipokines by adipose tissue, adipose tissue matrix, and adipocytes from visceral and subcutaneous abdominal adipose tissues of obese humans. Endocrinology 2004, 145, 2273-2282. [CrossRef] [PubMed]

85. Lona, J.M.F.; Martínez, M.S.; Alarcón, G.V.; Rodas, B.A.; Bello, J.R. El factor de necrosis tumoral $\alpha$ (TNF- $\alpha$ ) en las enfermedades cardovasculares: Biología Molecular y Genética. Gaceta Médica México 2014, 150, 334-344.

86. Ramírez Alvarado, M.; Sánchez Roitz, C. Tumor necrosis factor- $\alpha$, insulin resistance, the lipoprotein metabolism and obesity in humans. Nutr. Hosp. 2012, 27, 1751-1757.

87. Milenkovic, D.; Deval, C.; Gouranton, E.; Landrier, J.F.; Scalbert, A.; Morand, C.; Mazur, A. Modulation of miRNA expression by dietary polyphenols in apoE deficient mice: A new mechanism of the action of polyphenols. PLoS ONE 2012, 7, e29837. [CrossRef] [PubMed]

88. Adams, L.S.; Seeram, N.P.; Aggarwal, B.B.; Takada, Y.; Sand, D.; Heber, D. Pomegranate juice, total pomegranate ellagitannins, and punicalagin suppress inflammatory cell signaling in colon cancer cells. J. Agric. Food Chem. 2006, 54, 980-985. [CrossRef] [PubMed]

89. Tan, J.; Li, Y.; Hou, D.X.; Wu, S. The effects and mechanisms of cyanidin-3-glucoside and its phenolic metabolites in maintaining intestinal integrity. Antioxidants 2019, 8, 479. [CrossRef]

90. Tsuda, T.; Horio, F.; Uchida, K.; Aoki, H.; Osawa, T. Dietary Cyanidin 3-O- $\beta$-D-Glucoside-Rich Purple Corn Color Prevents Obesity and Ameliorates Hyperglycemia in Mice. J. Nutr. 2018, 133, 2125-2130. [CrossRef] [PubMed] 